\section{2}

\title{
Waveform inversion and focal mechanisms of two weak earthquakes in Cordillera Principal (Argentina) between $35^{\circ}$ and $35.5^{\circ} \mathrm{S}$
}

\section{ABSTRACT}

Only few (six) focal mechanism, in CMT Catalog, have been so far known for intraplate shallow events in the Andean chain close to Chile-Argentina state border at latitudes $\sim 35^{\circ} \mathrm{S}$. We add two more mechanisms, depths and moment magnitudes by carefully analyzing full waveforms of weak events recorded by broad-band stations of the Chile Argentina Geophysical Experiment (southern profile). The moment magnitudes of both events $(\mathrm{Mw}=3.6$ and 3.7) are lower than the duration magnitudes $(\mathrm{Md}=4.0$ and 4.29)reported by NEIC. The source depth, constrained by waveforms for one of the studied events $(5.5$ to $8.5 \mathrm{~km})$ seems to be considerably shallower than the hypocenter depth located by means of arrival times $(\sim 20 \mathrm{~km})$. The waveform analysis was complemented by first-motion polarities which resulted in an uncertainty assessment of the focal mechanism. Event 1 (2001-11-03) has a strike-slip mechanism with a small normal component and almost vertical nodal planes in the north-south and east-west directions. The north-south nodal plane could be related to the Calabozos faults system. Event 2 (2002-02-16) has a strike-slip mechanism with a small thrust component. The latter event (its subhorizontal nodal plane) could be associated with the El DiabloEl Fierro fault system.Dextral strike-slip solutions are consistent with recent studies in the area. 


\section{AUTORS}

2 *Raquel Villegas ${ }^{\mathrm{a}, \mathrm{b}}$ vraquelj@gmail.com, Jiri Zahradnikjiz@,karel.troja.mff.cuni.cz, Silvina

3 Nacif ${ }^{\mathrm{a}, \mathrm{d}}$ nacif.silvina@gmail.com, Silvana Spagnotto ${ }^{\mathrm{a}, \mathrm{e}}$ pampa113@gmail.com, Diego

4 Winocur ${ }^{\mathrm{f}}$ diegowinocur@hotmail.com and Flavia Leiva ${ }^{\mathrm{a}, \mathrm{d}}$ mariaflavialeiva@gmail.com

5

$6 \quad{ }^{a}$ Consejo Nacional de Investigaciones Científicas y Técnicas, Conicet, Argentina.

$7 \quad{ }^{b}$ Centro de Investigaciones en Ciencias de la Tierra, Universidad Nacional de Córdoba, Av. Vélez

$8 \quad$ Sarsfield 1611, Córdoba, Argentina.

$9{ }^{c}$ Charles University in Prague, Faculty of Mathematics and Physics, V Holesovickach 2, 18000

10 Prague, Czech Republic.

$11{ }^{d}$ Instituto Geofísico Sismológico F. Volponi, Universidad Nacional de San Juan, Ruta 12, Km 17,

12 Marquesado, Rivadavia, San Juan, Argentina.

$13{ }^{e}$ Departamento de Física, Universidad Nacional de San Luis, Ejército de los Andes 950, 5700, San

14 Luis Argentina

$15{ }^{f}$ Laboratorio de Tectónica Andina, Instituto de Estudios Andinos (UBA-CONICET)

16

$17 *$ Corresponding author (e-mail: Vraquelj@,gmail.com).

18 Phone number: +5403515353800. 
1

2

3

4

\section{Introduction}

The subduction of the Nazca plate beneath the South American plate generates the mountain building in the Andes. In these active margins large interplate underthrusting earthquakes occur and are the main goals of several research works(Christensen et al., 1988; Beck et al., 1998; Moreno et al., 2009; Lange et al., 2012; Ruiz et al., 2013; Lay, 2015; among others). Intraplate shallow earthquakes from the overriding plate exhibit lower magnitudes and their occurrence is less frequent (Figure 1.1). Those earthquakes are located in the forearc (Andean chain) and in the backarc. A noticeable aspect is the important seismicity increase between $\sim 33^{\circ}$ and $36^{\circ} \mathrm{S}$ documented by NEIC-USGSInternational Catalog. The only solution in CMT catalog at the latitudes analyzed in this paper is $\mathrm{Mw}=6.5,2004-08-28$. This solution is a strike-slip focal mechanism, which could be associated to the subduction obliquity of Nazca plate (Comte et al., 2008).

Focal mechanism solutions from waveform inversion techniques are generally available for earthquakes with magnitude greater than 5.0. However, in this region majority of the seismic events has magnitudes less than 5.0 (Figure 2.1). Therefore, the goal of this research is the application of moment tensor determination to waveform data availablefor events with magnitude less than 5.0 (http://www.iris.edu/SeismiQuery/). Every focal mechanism of these relatively weak events is important, even if they are not numerous. This study was made possible thanks to temporary network of the CHile ARgentina Geophysical Experiment (CHARGE), November 2000 to May 2002. We used two methods for crustal events on the high Andes to find their centroid moment tensor solution: ISOLA software (Sokosand Zahradník, 2008 and 2013) and a new approach called Cyclic Scanning of the Polarity Solution "CSPS" (Fojtíková and Zahradník, 2014). We combine the two techniques with intention to better resolve the mechanisms of the events recorded only by few stations. 

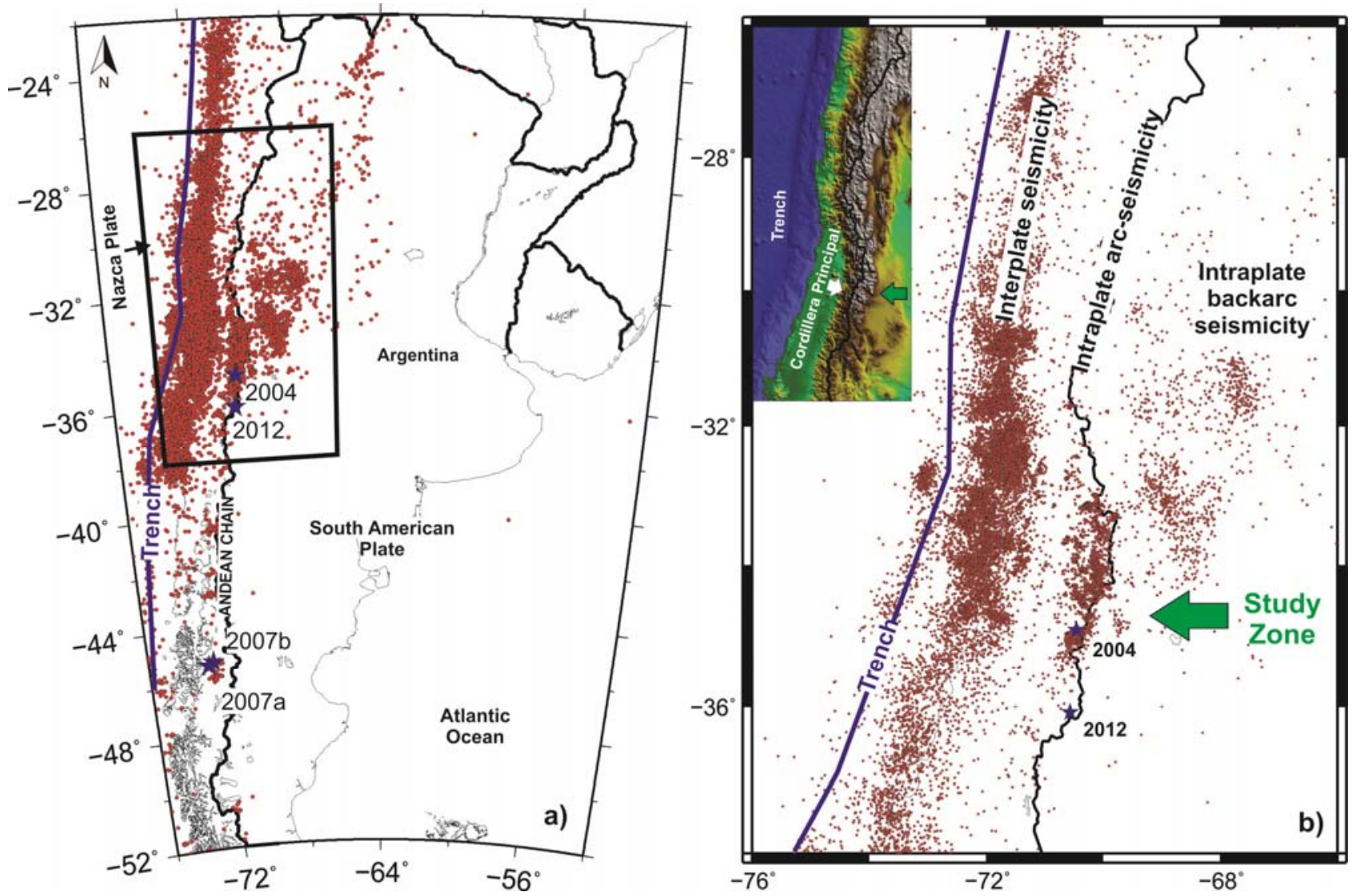

Figure 1.1 - Epicenters (red circles) from NEIC-Catalog (US Geological Survey) located between depths 0 and $50 \mathrm{~km}$ since January 1973 to January 2015. State borders are shown by thick black line and the Trench Zone by thick blue line; a) Blue stars denote the crustal seismicity located at the Andean chain with magnitude greater than 6.0. From north to south: M=6.5, August 28th 2004; $\mathrm{M}=6.0$, June 6th 2012; $\mathrm{M}=6.2$, April 21th 2007 and $\mathrm{M}=6.1$, April 1th 2007 (NEIC-Catalog). There is a noticeable seismicity increase below Andean chain between $\sim 33^{\circ}$ and $36^{\circ} \mathrm{S}$. The black box shows the region plotted in b); b) The western and eastern seismicity patterns represent the interplate events related with the contact of Nazca and South American plate and intraplate events (arc and backarc seismicity) related with the overriding South America plate, respectively. Inset: Topography and bathymetry from http://maps.ngdc.noaa.gov; the white and green arrows indicated the "Cordillera Principal" and the study zone, respectively.

\section{Seismotectonic Setting}

The zone of interest corresponds to the southern Central Andes comprising the high chain of Chile and Argentina from $35^{\circ} \mathrm{S}$ to $35.5^{\circ} \mathrm{S}$. At these latitudes, geological units and continental border strike NNE-SSW encompassing part of the southern volcanic zone. The Nazca plate is subducting underneath the South American plate with a normal angle of $27^{\circ}$ (Pardo et al. 2002, Anderson et 
1 al.2007) at a rate of $6.7 \pm 0.2 \mathrm{~cm} / \mathrm{yr}$, as constrained by GPS measurements along the Chile-Peru

2 oceanic trench (Kendrick et al., 2003). As is observed in Figure $1.1 \mathrm{~b}$, at the given latitudes

3 theCordillera Principal takes an important role, focusing the major seismic activity in the upper

4 plate. Also, the higher percentage of crustal seismicity is located on the western flank of the Andean

5 mountain chain as documented by the international catalog (NEIC-USGS or EHB-ISS), regional

6 data (Marot, 2013) and local data (Alvarado, 1998; Barrientos et al., 2004; Nacif, 2012; Marot,

7 2013). This seismicity is constrained to the first $20 \mathrm{~km}$ of the crust (Barrientos et al., 2004). Figure

$8 \quad 2.1$, a and b, shows the crustal seismicity $(0-50 \mathrm{~km})$ for the study region and surrounding areas

9 from NEIC Catalog (1973-2015) and the focal mechanism solutions from Harvard CMT (1976-

10 2015) and Alvarado et al.(2009). The $\mathrm{Mw}=6.5$ earthquake of August $28^{\text {th }} 2004$, located at a depth of

$1116 \mathrm{~km}$ (depth constrainedfrom HarvardCMT) and its aftershocks sequence were recorded by a local

12 network in Chile. The aftershocks, located at depths less than $15 \mathrm{~km}$, are distributed along a trend of

13 the NNE-SSW direction (Comte et al., 2008), consistently with one of the nodal plane from

14 Harvard CMT oriented NNE-SSW dextral strike-slip. In the NNEdirection at $\sim 70 \mathrm{~km}$ from the 2004

15 earthquake a similar solution was found (Harvard CMT) for Mw=5.9, September $13^{\text {th }} 1987$

16 earthquake. The actual state of the Cordillera Principal, proposed by Farías (2007), principally

17 presents a dextral kinematic with a forearc moving toward to the north. Also, thrust solutions are

18 resolved by Harvard CMT. Additionally, Alvarado et al.(2009), using body-wave modeling

19 estimated fault orientation, depth and size of $\mathrm{Mw}=6.3$, September $4^{\text {th }} 1958$, "Las Melosas"

20 earthquake. They found a focal mechanism solution with nodal planes on an east-west and north-

21 south direction with either right-lateral and left-lateral displacement, respectively. Their

22 interpretation focused on the activation of east-west structures, which could be accommodating

23 differences in the higher and lower shortening to the north and south of $\sim 33^{\circ} \mathrm{S}$ respectively. 




Figure 2.1 - a) The map shows the crustal seismicity for the study region for depth from 0 to $50 \mathrm{~km}$. Red circles: epicenters from NEIC catalog from January 1973 to January 2015. Focal mechanism solutions from Harvard CMT Catalog (beachball in purple) and Alvarado et al.(2009; beachball in green). These are shown by lower hemisphere projections with dark colors indicating compressional quadrants.Argentina-Chile state border is shown by thick black line; b)Histograms of the focal depth and magnitude for seismic events plotted in a). Most of events have depth less than $20 \mathrm{~km}$ and magnitude lower than 5.0 consistently with Barrientos et al.(2004). principal directions of the maximum horizontal compressional stress " $\sigma H m a x "$. They obtained a NNE-SSW direction for $\sigma \mathrm{Hmax}$ at $\sim 34^{\circ} \mathrm{S}$.

\section{Data}

Data are from CHile ARgentina Geophysical Experiment (CHARGE) recordedfrom November 2000 to May 2002. Stations were disposed in two E-W transects at $30^{\circ} \mathrm{S}$ and at $36^{\circ} \mathrm{S}$, with other 
1 stations deployed between those transects ( 22 broadband stations in total). In this work only data

2 from the southern transect were used (Figure 3.1). Seismic events (magnitude $\geq 4$ ) located at high

3 Andes by U.S. Geological Survey (NEIC-Catalog) were selected. The waveform data from IRIS

4 Seismic Query (http://www.iris.edu/SeismiQuery/breq_fast.phtml) were downloaded. We relocated

5 events using Hypocenter (Lienert and Havskov, 1995) which runs in SEISAN (Havskov et al., 6 2007).

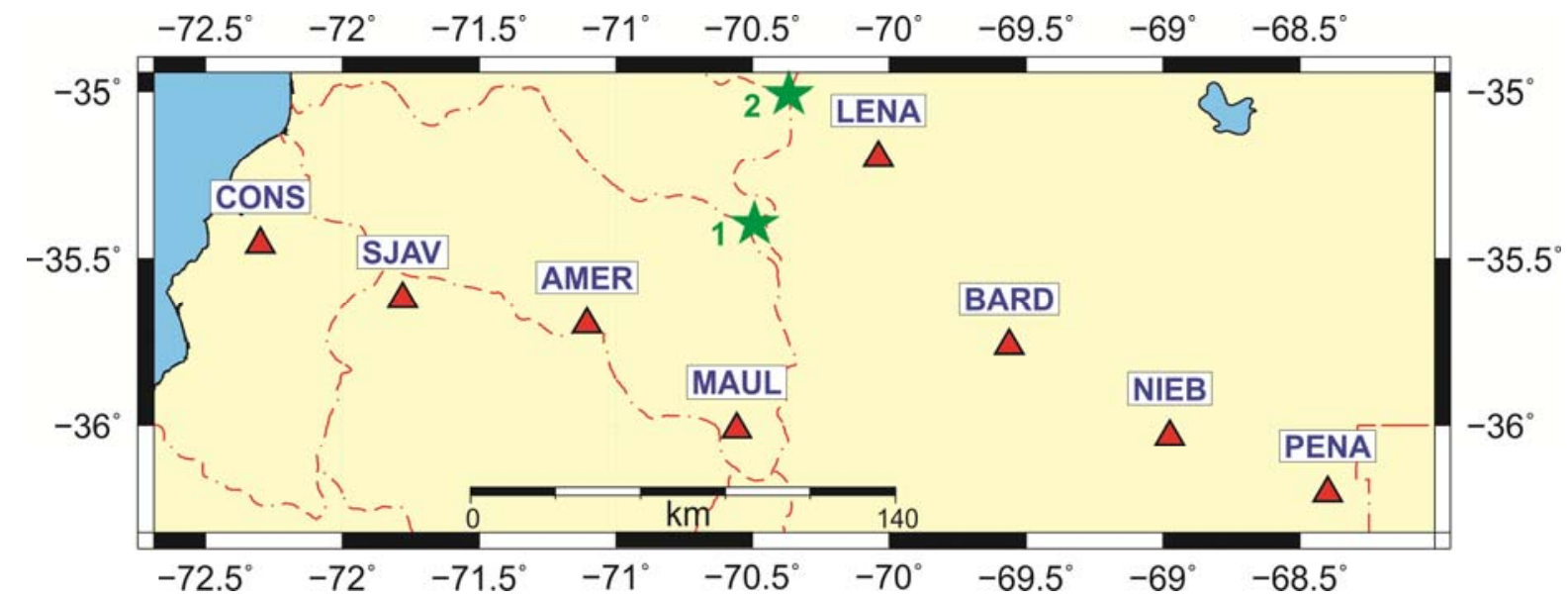

Figure 3.1 - Map with the station locations used in this work (indicated with red triangles). Those stations represent the CHARGE southern profile.Additionally, just for polarity reading, one station of the other transect of this project was also used, station LITI located at $31^{\circ} \mathrm{S}$ and $71^{\circ} \mathrm{W}$, which is outside of this figure. The green stars (denoted 1 and 2) indicate the epicenters of two events studied in the present paper.

\section{Methodology}

The focal mechanism solution is one of the most important parameters of an earthquake and the

17 focal mechanisms represent the first step to determine the stress regime of a region under study. Our

18 goal is to calculate the focal mechanism, depth and size of 2 earthquakes of relatively small magnitudes ( $\mathrm{Md}$ between 4 and 4.2) in the region of interest. Two methods were 
1 used:ISOLAsoftware (Sokos and Zahradník, 2008 and 2013) and the CSPS code (Fojtíková and

2 Zahradník, 2014).

3 ISOLA runson Matlab platformallowing the users an easy interaction. ISOLA calculates the

4 centroid moment tensor solution of an earthquake based on the least-squares inversion of

5 fullwaveforms, assuming a point-source representation (multiple point sources can be studies as

6 well, but were not used in the present paper). The program can be used for local and regional

7 events. Green's functions are calculated by the discretewavenumber method (Bouchon,

8 1981).Thecentroidposition and centroid time are calculated by a grid search. The eigenvectors of

9 themoment tensor provide the strike, dip and rake angles. The eigenvalues provide the scalar

10 moment $\left(\mathrm{M}_{0}\right)$ and decomposition of the moment tensor in three parts:double couple (DC),

11 compensated linear vector dipole (CLVD) and isotropic or volumetric component (VOL). Their

12 relative size is expressed in percentages; in this paper we focus on the double-couple percentage,

13 denoted $\mathrm{DC} \%$. Optionally, a deviator inversion can be calculated (VOL $=0)$; just this is the case of

14 all ISOLA applications in the present paper. The low- and high-frequency limit of the waveform

15 inversion are determined by the noise (either natural or instrumental) and by a given epicentral

16 distance and quality of the velocity model,respectively (Fojtíková and Zahradník, 2014).The best

17 solution is the one having the least residual error, which is equivalent to maximizing the correlation

18 between the observed and synthetic seismograms; their match is measured by variance reduction

19 (VR), which should be as close to 1 as possible.. Resolvability of the moment tensor is quantified

20 by the condition number $(\mathrm{CN})$, which is the ratio between the maximum and minimum singular

21 value of the Green's function matrix (Zahradník and Custodio, 2012). It is a relative measure, the

22 smaller and larger $\mathrm{CN}$ values corresponding to well-posed and ill-posed inverse problems,

23 respectively. The methodical details are described in Krizova et al.(2013). 
For events recorded at only few stations some additional constraints are needed, for example the

2 first-motion polarities. This is the idea of the CSPS method (Fojtíková and Zahradník, 2014). To

3 applythe CSPS code a set of polarity solutions must be provided, e.g. using codeFOCMEC(Snoke,

4 2003). The strike/dip/rake triplet from each FOCMEC solution is then used as input for the

5 waveform inversion in which scalar moment, source position and centroid time are calculated.Every

6 solution is quantified by variance reduction (VR) and a subset of admissible solutions is

7 determined.To define the admissible CSPS solutions, a range close to the optimal solution is

8 chosen, for example, the interval between 0.95VRopt and VRopt, where VRopt denotes the best

9 fitting solution.The advantage of CSPS is not only in using both waveforms and polarities, but also

10 in explaining data with $100 \%$ DC source model.

11 Recently, the CSPS method has been also implemented in ISOLA software (unpublished 12 modification by E. Sokos), but, for simplicity, hereafter we speak about ISOLA and CSPS as about 13 two independent codes.

\section{Results}

17 The velocity model of Spagnotto (2013; see Table 1) was used for the calculation of the location 18 and focal mechanisms, both with FOCMEC and ISOLA. The selected earthquakes with their 19 location parameters obtained in this work using HYPOCENTER and their NEIC magnitude are 20 shown in Table 2.

Table 1 - Spagnotto's velocity model. The estimated depth of Mohorovicic's discontinuity is of $55 \mathrm{~km}$ of depth according to this model

\begin{tabular}{ccc}
\hline $\begin{array}{c}\text { Depth of } \\
\text { Layer top }(\mathrm{km})\end{array}$ & $\mathbf{V p}(\mathrm{km} / \mathrm{s})$ & $\mathbf{V s}(\mathrm{km} / \mathrm{s})$ \\
\hline 0.0 & 5.12 & 3.185 \\
\hline
\end{tabular}




\begin{tabular}{cll}
\hline 5.0 & 5.69 & $3.373 \mathbf{1}$ \\
\hline 10.0 & 5.84 & 3.374 \\
20.0 & 6.39 & $3.634 \mathbf{2}$ \\
35.0 & 6.84 & 3.947 \\
45.0 & 7.24 & $3.948 \mathbf{3}$ \\
55.0 & 7.42 & 4.166 \\
90.0 & 8.18 & $4.696 \mathbf{4}$ \\
120.0 & 8.69 & 4.888 \\
\hline 210.0 & 8.76 & $4.940 \mathbf{5}$ \\
\hline
\end{tabular}

6

7

8 Earthquakes occurring in the period of duration of the CHARGE project and near the CHARGE

9 stations were sought. From this set, earthquakes of magnitude Md (NEIC) greater than 4 were

10 selected due to the geometry of the network of stations and the noise observed in the records.

Table 2 - Events selected for processing

\begin{tabular}{c|ccccccccc|} 
Event & Date & $\begin{array}{c}\text { Origin Time } \\
(\mathrm{GMT})\end{array}$ & Latitude & Longitude & $\begin{array}{c}\text { Depth } \\
(\mathrm{km})\end{array}$ & $\begin{array}{c}\text { Latitude } \\
\text { error }(\mathrm{km})\end{array}$ & $\begin{array}{c}\text { Longitude } \\
\text { error }(\mathrm{km}\end{array}$ & $\begin{array}{c}\text { Depth } \\
\text { error }(\mathrm{km})\end{array}$ & $\begin{array}{c}\text { Magnitude } \\
(\mathrm{Md})\end{array}$ \\
\hline 1 & $2001-11-03$ & $16: 30: 8.2$ & $-35.371^{\circ}$ & $-70.526^{\circ}$ & 21.0 & 2.9 & 1.7 & 3.1 & 4.0 \\
2 & $2002-02-16$ & $06: 33: 8.8$ & $-35.059^{\circ}$ & $-70.430^{\circ}$ & 18.1 & 2.0 & 0.8 & 1.6 & 4.2 \\
\cline { 2 - 10 }
\end{tabular}

\subsection{Event1:}

This event occurred on 3th November 2001; see more details in Table 2.

5.1.1 InversionwithISOLA

17 We inverted full waveforms at 5 stations (MAUL, BARD, SJAV, NIEB, PENA) using ISOLA

18 without any prior first-motion polarity constraint, see Figure 5.1. The frequency range was 0.05 to

$190.08 \mathrm{~Hz}$, and the grid search was below epicenter at depths from 2.5 to $41.5 \mathrm{~km}$. As a result of this

20 first stage of data processing we obtain a thrust mechanism whose parameters are listed in Table 3.

21 The best-fitting mechanism is well constrained, with the condition number as low as $\mathrm{CN}=2.1$. The

22 depth grid search is quite stable as regards to the moment magnitude $\mathrm{Mw}=3.6$. The depth is poorly 
1 resolved, with formally best fitting solution at $8.5 \mathrm{~km}$, but well acceptable depths are in the range

2 from 5.5 to $\sim 30 \mathrm{~km}$, i.e. including the hypocenter depth $(21 \mathrm{~km})$. Comparing with the first-motion

3 polarities, weobserve that the best-fitting (thrust) solution of ISOLA (depth $8.5 \mathrm{~km}$ ) disagrees with

44 polarities: BARD, NIEB, PENA and MAUL.In this sense standard ISOLA does not provide a

5 solution compatible with polarities. However, note that at shallow depth $(5.5 \mathrm{~km})$, close to the best-

6 fitting thrust mechanism, a strike-slip mechanism also appears in the standard ISOLA solution, and

7 its waveform fit is almost as good as that of the thrust. Below we see that just this solution is

8 preferable when jointly inverting polarities and waveforms by CSPS method.

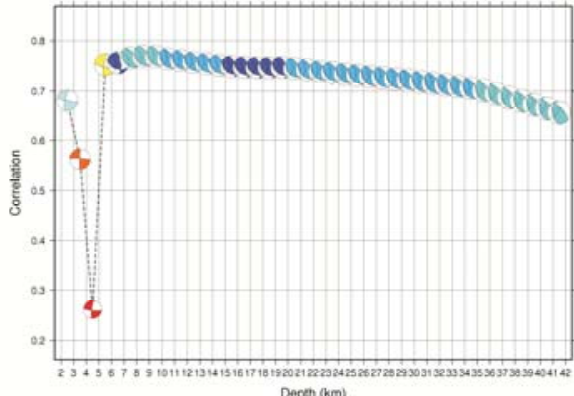

a)

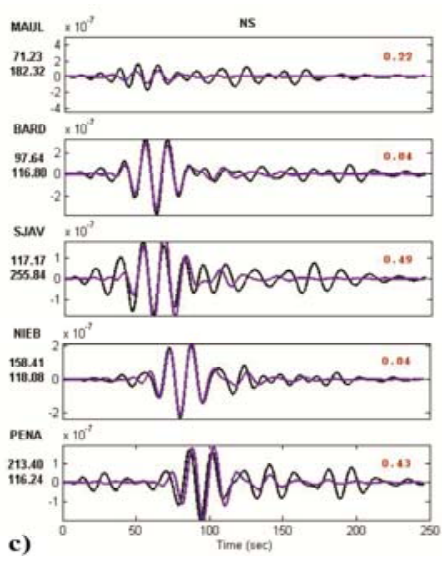

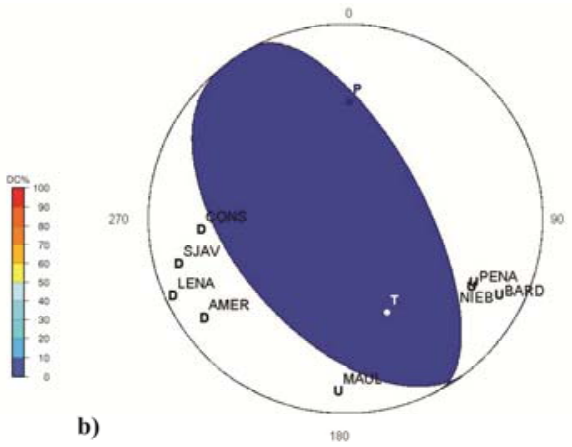

b)


Figure 5.1- Event 1 a) Correlation diagram demonstrating variation of the focal mechanism with the trial source depth. The optimal solution is at the depth of $8.5 \mathrm{~km}$; b) The beachball representing the optimal solution calculated by ISOLA, compared with the observed first-motion polarities for the $8.5 \mathrm{~km}$ depth; c) Observed (black) and synthetic (purple) waveforms in the frequency range between 0.05 and $0.08 \mathrm{~Hz}$. Shown in the plot are displacements (in meters). The number in the top right of each box shows variance reduction of the corresponding component. Numbers under the station codes indicate the: epicentral distance (km) and azimuth (degree), respectively. 
2 Using 8 polarities from stations AMER, MAUL, PENA, NIEB, BARD, CONS, SJAV and LENA,

3 we calculate all possible first-motion polarity solutions with FOCMEC, allowing no polarity misfit.

4 Logically, in FOCMEC we should use the hypocenter depth $(21 \mathrm{~km})$. However, the source depth

5 used to project polarities on the focal sphere needs a careful consideration of the inner crustal

6 discontinuities existing in the velocity model. For example, for the source depth of $21 \mathrm{~km}$, the

7 takeoff angle of almost all used stations is $>90^{\circ}$, corresponding to upgoing rays; this is the effect of

8 the 20-km discontinuity. Decreasing the assumed source depth just slightly below $20 \mathrm{~km}$ (e.g. 19 or

$918 \mathrm{~km}$ ), the polarity projections on focal sphere are more realistic due to waves refracted at the

10 inner-crustal discontinuities (downgoing rays). Therefore, taking into account possible inaccuracies

11 of the location and velocity model, we adopt the latter approach (assuming the source depth of 18

$12 \mathrm{~km}$ to generate FOCMEC solutions).

13 The resulting focal mechanisms calculated with FOCMEC have a significant uncertainty (Figure

145.2 a). The plot includes diverse solutions; therefore it is important to check which of them agree

15 with waveforms. The latter can be made by the CSPS method. We employ the same five stations as

16 in the application of standard ISOLA in the section 5.1.1. The frequency range and the trial source

17 depths are also the same as in the previous section.

18 We apply the CSPS method and set up a range of admissible CSPS solutions in the interval between

190.90 VRopt and VRopt and find 11 solutions with VRopt $=0.56$ (see Figure $5.2 \mathrm{~b}$ and Table 3).In

20 this case, we do not find the thrust mechanisms, as obtained with standard ISOLA, but the solution

21 has a strike-slip mechanism at shallow depth. The most important progress after application of

22 CSPS is that now the focal mechanism is in accordance with all polarities (Figure $5.2 \mathrm{c}$ and d). The

23 moment magnitude is quite stable over the 11 admissible solutions (Mw 3.5-3.6). The depth of these

24 solutions varies from $5.5 \mathrm{~km}$ (the best-fitting depth) to $10.5 \mathrm{~km}$. 
a)

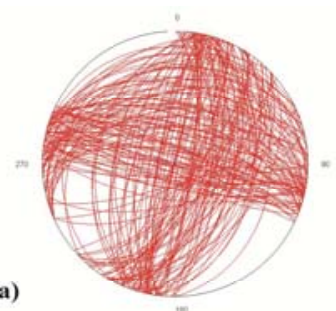

b)
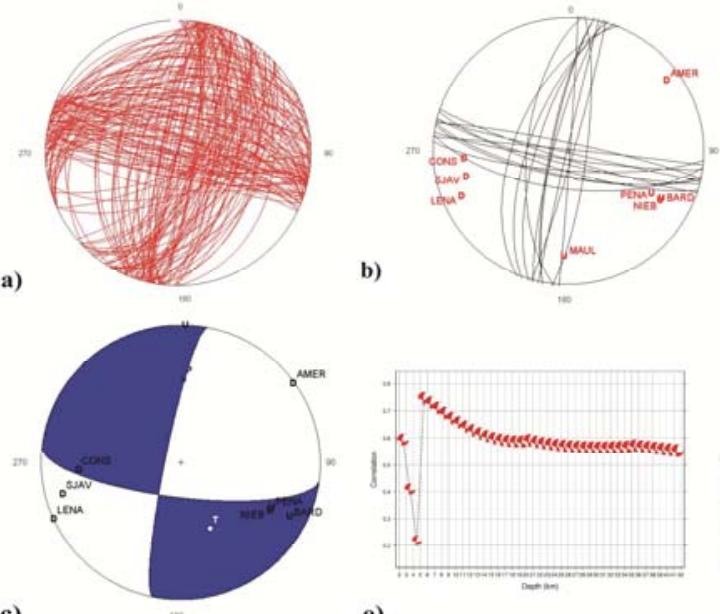

c)

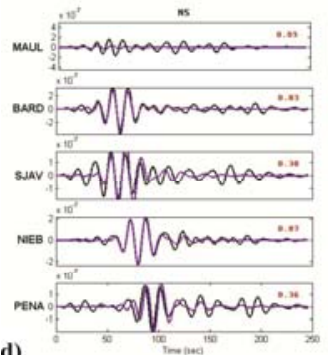

e)


3 other stations could not be fit is a larger noise compared to Event 1, and/or the larger sourcedepth.

Figure 5.2-Event 1a) Solutions found with FOCMEC for source depth $18 \mathrm{~km}$; b) Admissible solutions found with the CSPS method, ranging between 0.90 VRopt and VRopt $=0.56$; c) Beachball representing the optimal solution found with the CSPS method at 5.5 $\mathrm{km}$; d) Correlation diagram demonstrating variation of the waveform match with the trial source depth, using the optimal mechanism; e) Observed (black) and synthetic (purple) seismograms graphic fit.

\subsection{Event 2}

This event occurred on $16^{\text {th }}$ February 2002, see Table 2 . Although, according to NEIC, its magnitude $(M d=4.2)$ is even slightly larger than the magnitude of Event $1(M d=4.0)$, the waveform inversion of Event 2 was feasible only for the nearest station (LENA). The likely reason why the We return to this problem in the Discussion and Conclusion section. 

constrained (ill-posed) problem. Thus the calculated mechanism has a very limited physical meaning unless confirmed by independent data. The first-motion polarities belong to such data, and, perhaps surprisingly, we find that the nodal planes are in agreement with the polarities projected on focal sphere for the $18 \mathrm{~km}$ depth (Figure $5.3 \mathrm{~b}$ ). The moment magnitude is $\mathrm{Mw}=3.7$, i.e. polarities into joint inversion, using the CSPS method.

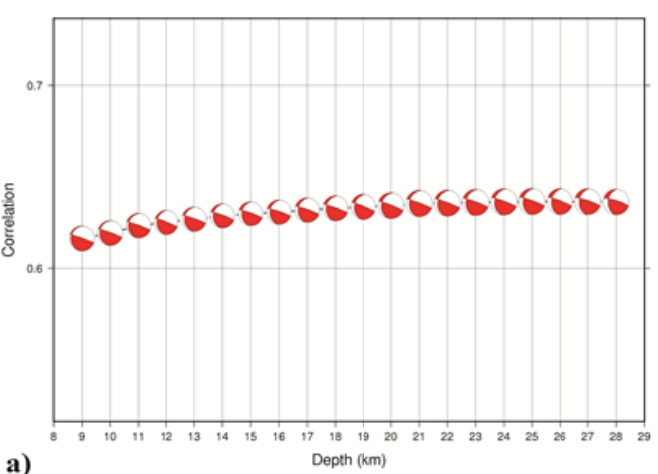

a)

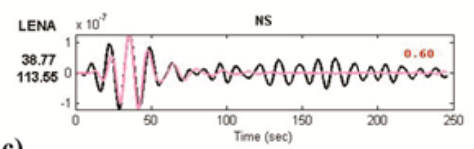

b)
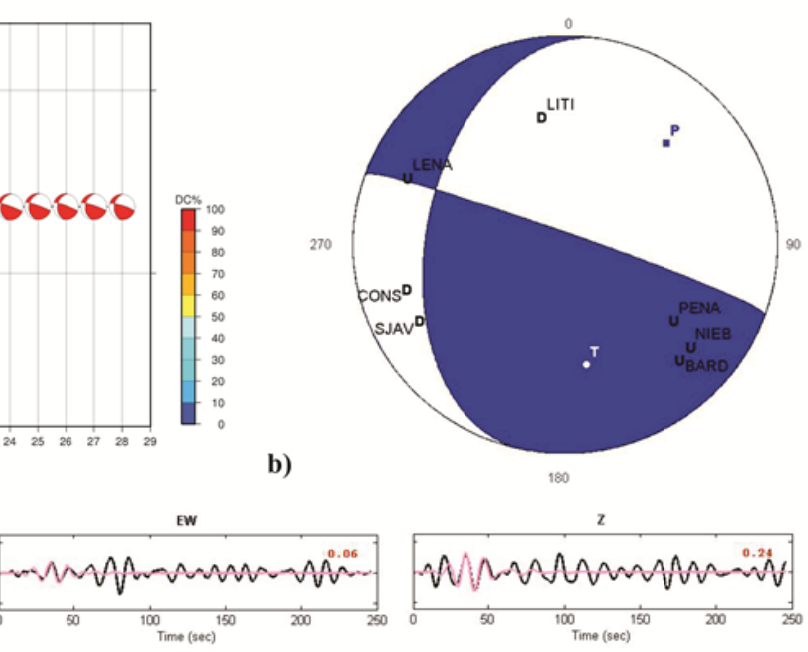

Figure 5.3 - Event 2 a) Correlation diagram demonstrating variation of the focal mechanism with the trial source depth; b) The beachball representing the optimal solution calculated by ISOLA, compared with the observed first-motion polarities for the $18 \mathrm{~km}$ depth; c) Observed (black) and synthetic (pink) waveforms in the frequency range between 0.06 and $0.1 \mathrm{~Hz}$. Shown in the plot are displacements (in meters). The number in the top right corner of each box shows variance reduction of the corresponding component. Numbers under the station codes (left) indicate the: epicentral distance (km) and azimuth (degree), respectively. 
1 The focal mechanisms were calculated in FOCMEC with 6 stations (PENA, NIEB, BARD, CONS,

2 SJAV and LENA). Assuming the source depth of $18 \mathrm{~km}$, we get a suite of very variable solutions;

3 see Figure 5.4 a. Then the CSPS method was applied with LENA station, using similar

4 computational parameters as in Section 5.2.1. Choosing the admissible interval between 0.50 VRopt

5 and VRopt $=0.33$ (Figure $5.4 \mathrm{~b}$ ), intentionally broader than for Event 1 (because we have just one

6 station with inverted waveforms) we find 3 solutions. In this case the best CSPS solution is

7 practically the same as the standard ISOLA solution (Table 3). We can say that all admissible

8 solutions cluster near the best solution. However, the moment magnitude range obtained by CSPS is

9 relatively broad (3.3-3.7), and the depth range is between $15-23 \mathrm{~km}$.

10

11 Table 3 - Focal mechanism of the studied events. The $\left(^{*}\right)$ indicates possible fault plane, discussed in the text.

\begin{tabular}{|c|c|c|c|c|c|c|}
\hline Event & Method & Centroid depth $(\mathrm{km})$ & Strike / Dip / Rake & $\mathrm{Mw}$ & VR & $\mathrm{DC}(\%)$ \\
\hline \multirow{2}{*}{1} & ISOLA & 8.5 & $\begin{array}{l}141^{\circ} / 37^{\circ} / 81^{\circ} \\
332^{\circ} / 53^{\circ} / 97^{\circ}\end{array}$ & 3.6 & 0.59 & 26 \\
\hline & CSPS & $5.5-10.5$ & $\begin{array}{c}97^{\circ} / 67^{\circ} /-11^{\circ} \\
191^{\circ} / 80^{\circ} /-157^{\circ}(*)\end{array}$ & $3.5-3.6$ & 0.56 & 100 \\
\hline \multirow[b]{2}{*}{2} & ISOLA & 25 & $\begin{array}{c}191^{\circ} / 31^{\circ} / 170^{\circ}\left(^{*}\right) \\
289^{\circ} / 85^{\circ} / 59^{\circ}\end{array}$ & 3.7 & 0.40 & 96 \\
\hline & CSPS & $15-23$ & $\begin{array}{l}197^{\circ} / 28^{\circ} / 178^{\circ} \\
289^{\circ} / 89^{\circ} / 62^{\circ}\end{array}$ & $3.3-3.7$ & 0.33 & 100 \\
\hline
\end{tabular}

12 
a)
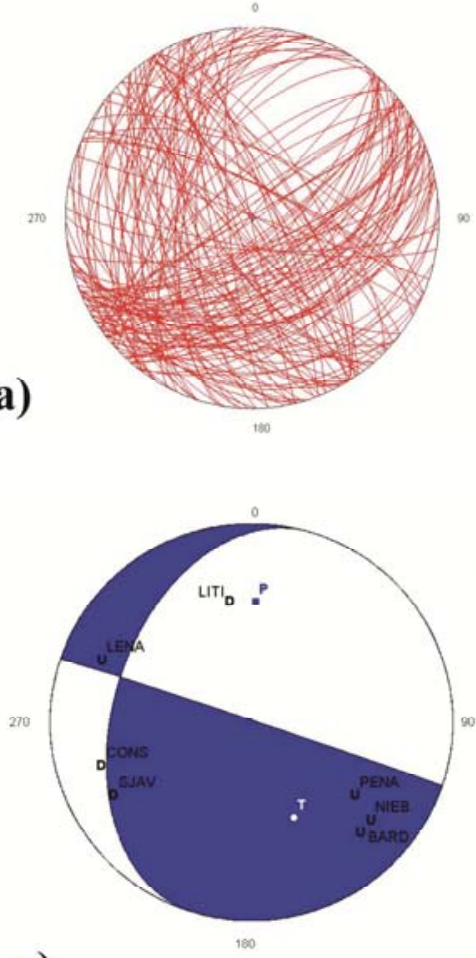

c)

Figure 5. 4-Event 2 a) Solutions found with FOCMEC for the source depth of $18 \mathrm{~km}$; b) Admissible solutions found with the CSPS method, ranging between 0.50 VRopt and VRopt $=0.33$; c) Beachball representing the optimal solution found with the CSPS method, polarities plotted for the depth of $18 \mathrm{~km}$; d) Observed (black) and synthetic (pink) seismograms graphic fit. b)

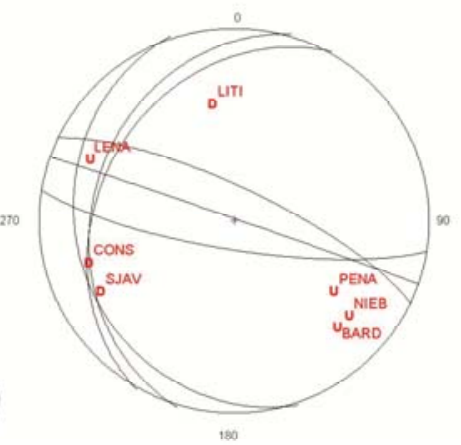

NS

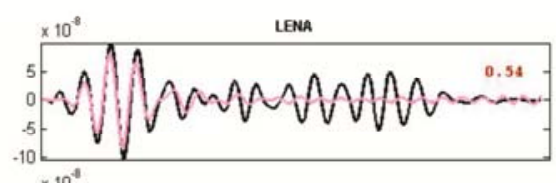

EW

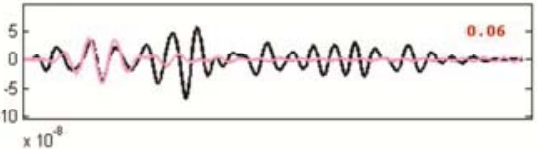

z

d)

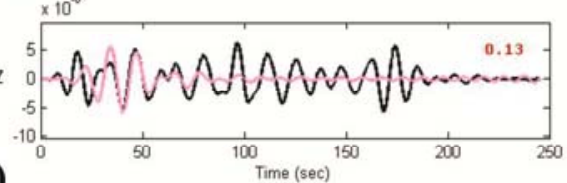

(1)

region, Cordillera Principal of Argentina between $-35^{\circ}$ and $-35.5^{\circ}$ latitude, has been so far very limited; just six solutions have been published. Therefore, the aim of the present paper was to calculate at least a few more mechanisms by waveform inversion, making use of broad-band data from the recent temporary seismic experiment CHARGE. Preliminary tests and an intensive search for usable data resulted in 2 events (Table 2). Their focal mechanisms, included in Figure 5.5, were studied in detail using two methods, ISOLA and CSPS. 
Different techniques had used to obtain the principal stress orientations from a population of

2 focal mechanisms or from the original data of polarities and take-off angles used to calculate them

3 (Harmsen and Rogers, 1986; Rivera and Cisternas, 1990; Reyners et al., 2002). In the region under

4 study, considering the few focal mechanisms available, we cannot make assumptions about the

5 stress pattern. However we suggest some hypotheses (which are not the unique) to explain the focal

6 mechanisms obtained in this work. A rigorous tectonic regime can be assigned when more

7 earthquake focal mechanisms from local or regional studies become available.

8 The Event 1 present two solutions, strike-slip mechanism with a normal component (Figure 5.2

9 c) and thrust mechanism (Figure 5.1 b). The more robust solution is the strike-slip solution

10 considering it is in agreement with polarities. The CSPS method has shown that the two nodal

11 planes are well constrained (Figure $5.2 \mathrm{~b}$ ). The moment magnitude of this event is well resolved

$12(\mathrm{Mw}=3.6)$, and it is lower than the NEIC estimation $(\mathrm{Md}=4.0)$, but bear in mind the difference

13 between the methods of calculating both magnitudes. In contrast to the hypocenter location $(21 \mathrm{~km})$,

14 the CSPS method suggests a very shallow depth (5.5 and $8.5 \mathrm{~km})$. This disagreement may be caused

15 by the relatively large epicentral distances of the stations used. To locate reliably a shallow event

16 like this by means of first arrival times we would need $\mathrm{P}$ and $\mathrm{S}$ readings from stations at epicentral

17 distances of the order of $\sim 10 \mathrm{~km}$, or less, and a very detailed velocity model of the uppermost

18 crustal layers. The waveform inversion at the available stations (epicentral distances between 71

19 and $213 \mathrm{~km}$ ) is more sensitive to the shallow depth because the records contain also surface waves.

20 This issue has to be studied in more detail elsewhere, similarly to the disagreement between

21 hypocenter and centroid depth found by Zahradnik et al. (2008) and Janský et al. (2009), but the

22 obtained indication of a very shallow depth is rather strong. The thrust mechanism of Event 1 and

23 the centroid depth similar to the hypocenter depth cannot be ruled out, but with the existing velocity

24 model such a solution seems less likely due to a few polarity disagreements. 
From a geological analysis, this earthquake (Event 1) is located at the western part of the

2 Malargüe Fault and Thrust belt. This is a typical thick skinned structural style related to the partially

3 inverted Mesozoic deposits to the Neuquén basin (Giambiagi et al., 2009). The focal mechanism of

4 this earthquake could be related to the movement of the Calabozos fault system described at field

5 studies by Tapia (2010). This fault was described like a reverse fault dipping 20 to $30^{\circ} \mathrm{W}$ up to

$660^{\circ} \mathrm{W}$ and oriented N-S up to NNW-SSE. Particularly, this sector not has geophysical studies

7 related to the microearthquakes but, one of the field observations of Tapia (2010) were that this

8 fault cut the glacial and post-glacial sequence concluded has quaternary activity. According with

9 Farías et al. (2010) the current state of the Cordillera Principal would have a kinematic

10 predominantly dextral with a forearc advancing north, that is consistent with a dextral strike slip

11 component and nodal plane located in N-S direction. The reverse component is better explained by

12 the Calabozos fault.

13 The analysis of Event 2 is more difficult, because the waveforms could be successfully modeled 14 only with a single (nearest) station. As such, with just a single station, the standard waveform 15 inversion with ISOLA is very poorly constrained. Nevertheless, in this particular case the ISOLA 16 solution luckily satisfies the first-motion polarities, thus the best CSPS solution and ISOLA solution 17 are the same. The mechanism is a thrust with a strike-slip component. The CSPS method provides 18 an uncertainty estimate, showing that the admissible solutions form a relatively compact cluster 19 around the best-fitting solution. The centroid depth is poorly constrained, but the hypocenter depth $20(18 \mathrm{~km})$ is not ruled out. The moment magnitude ( $\mathrm{Mw} \sim 3.3-3.7)$ is also poorly constrained, although 21 definitely lower than the $\mathrm{Md}=4.2$ of NEIC.

22 Event 2 could be related to the El Diablo-El Fierro fault system. This fault corresponds to the 23 eastern border of the Abanico basin (Charrier et al., 2002). The plane of the fault is oriented N-S to 24 NNE-SSW dipping west and correspond to the tectonic contact between Cenozoic and Mesozoic 
1 sequences. This fault has a normal movement at Mesozoic and Eocene-Oligocene times and was

2 partially inverted at the Miocene. These compressive movements correspond to the tectonic

3 inversion of the Abanico Basin (Charrier et al., 2002).

$4 \quad$ The El Diablo-El Fierro fault system has several microerthquakes along this fault recognized by 5 many authors (Comte et al, 2008; Farías et al., 2008). The associated seismic activity implies that

6 this structure is still active and participates in the present-day adjustments of the Andean crust. The 7 shallow earthquake of $\mathrm{Mw}=6.5$ of August 28th, 2004, was studied by Comte et al. (2008), and had

8 the solution similar to the event 2 analyzed in this work. Both are possibly associated with the El

9 Diablo-El Fierro fault system have strike-slip displacements and N-S or NNE-SSW oriented vertical

10 planes. The only difference in this comparison is the event 2 has a subhorizontal plane. This could

11 be related to the detachment level at depth of this fault system like was proposed by Charrier et 12 al.(2002), Farías et al. (2010), y Piquer et al. (2010) at these latitudes. According with Farías (2007)

13 the current state of the Main Cordillera would have a kinematic predominantly dextral course with a 14 forearc toward advancing to the north.

15 Dextral strike-slip solutions strike-slip dextral are consistent with recent studies in the area, which 16 show that the region had evidence of these structures (Tapia et al. 2015), which were reactivated by 17 the earthquake of February 27, 2010, Maule, Chile (Lupi and Miller, 2014 ;and Spagnotto et al., 18 2015). 


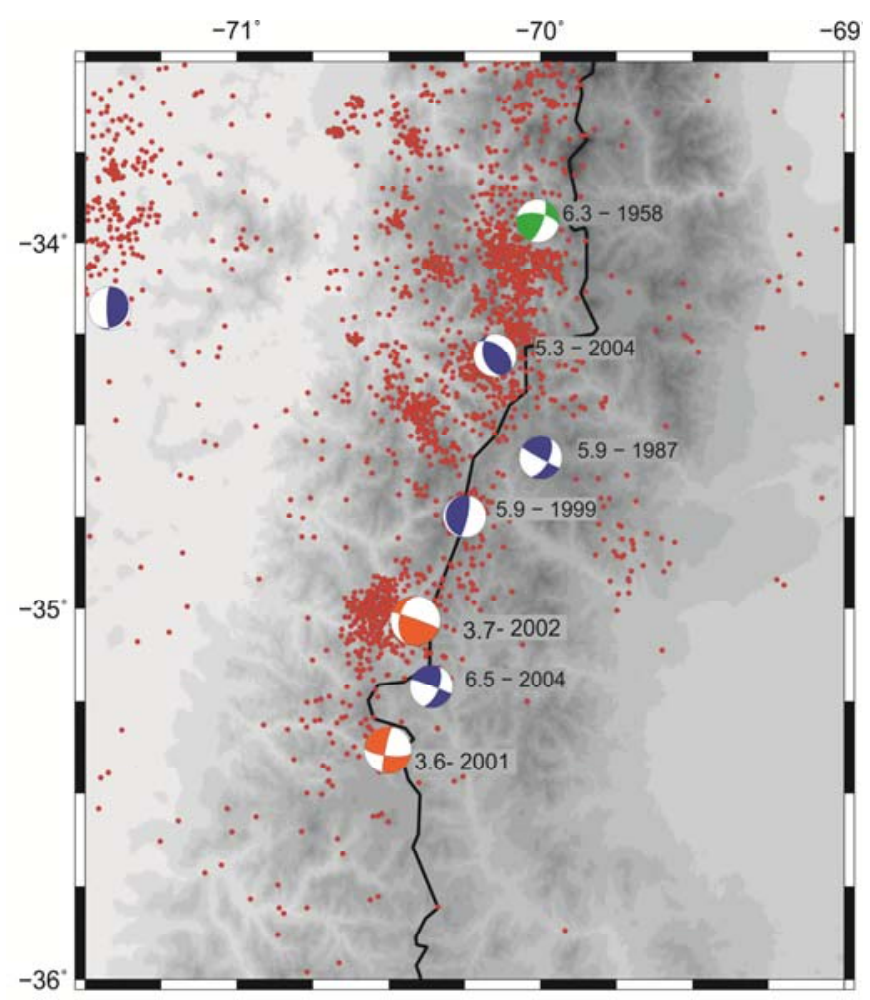

$\frac{1}{2}$ 3

4

6 7 8 that its north-south nodal plane with right lateral displacement could be associated with Calabozos

13 fault system. The magnitude $\mathrm{Mw} 3.6$ achieved for this event is lower than the magnitude provided

Figure 5.5 -Same as in Figure 2.1, but including the two mechanisms calculated in the present paper (in orange).

4 Although two mechanisms were added to the previously existing six mechanisms, future

investigation in the region should considerably increase the number of reliably inverted events, optimally with temporary local networks.

\section{Conclusion}

In this work focal mechanisms of two crustal seismic events in the Andean chain were obtained.

The southernmost event (Event 1) has a strike-slip solution with a normal component. We proposed by NEIC $(\mathrm{Md}=4.0)$. Also the depth obtained from waveforms $(5.5-5.8 \mathrm{~km})$ is considerablysmaller than the hypocenter location depth $(21 \mathrm{~km})$. For the northernmost event (Event 2), characterized by a 
1 strike-slip solution with a small thrust component, we suggested an interpretation in terms of an

2 activation of a detachment level of the El Diablo-El Fierro thrust system fault. The magnitude is

3 poorly constrained (3.3-3.7), but definitely lower than that of NEIC $(\mathrm{Md}=4.2)$. The depth for this

4 event from the waveform inversion methods varies in a broad range, so in this case our

5 preferredhypocenter location depth is $18 \mathrm{~km}$. Such depth is also related with our interpretation of

6 the activated detachment level and with subhorizontal nodal plane being the fault plane.

7 The difference between the obtained magnitudes and NEIC magnitudes is understandable

8 considering that NEIC reports duration magnitude. Future studies are needed to establish scaling

9 relations between various magnitudes of small events (Md, ML, Mw) in the studied region.

12 7. Acknowledgments

13 The facilities of the IRIS Data Management System, and specifically the IRIS Data Management 14 Center, were used for access to waveform, metadata or products required in this study. The IRIS

15 DMS is funded through the National Science Foundation and specifically the GEO Directorate 16 through the Instrumentation and Facilities Program of the National Science Foundation under

17 Cooperative Agreement EAR-0552316. Some activities of are supported by the National Science

18 Foundation EarthScope Program under Cooperative Agreement EAR-0733069.One of the authors

19 (J.Z.) has been supported from the Czech Science Foundation grant GACR-14-04372S. The authors 20 wish to thank to Efthimios Sokos and Lucia Fojtíková for valuable help during this work.

\section{Bibliography}




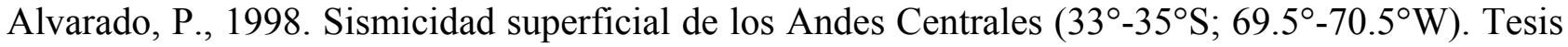
de Magister en Ciencias, mención Geofísica. Departamento. Geofísica, Universidad de Chile. Pp.

3161 . Alvarado, P., Barrientos, S., Sáez, M., Astroza, M., Beck S., 2009. Source study and tectonic implications of the historic 1958 Las Melosas crustal earthquake, Chile, compared to earthquake damage. Physics of the Earth and Planetary Interiors, 175, 26-36, doi:10.1016/j.pepi.2008.03.015 Anderson, M.L., Alvarado, P., Zandt, G., Beck S., 2007. Geometry and brittle deformation of the subducting Nazca Plate Central Chile and Argentina. Geophysical Journal International, 171, 419434.

Barrientos, S., Vera, E., Alvarado, P., Monfret T., 2004. Crustal seismicity in central Chile. Journal of South American Earth Sciences, 16, 759-768.

Beck, S., Barrientos, S., Kausel, E., Reyes M., 1998. Source characteristics of historic earthquakes along the central Chile subduction zone. Journal of South American Earth Sciences, 11, 115-129.

Bouchon, M., 1981.A simple method to calculate Green's functions for elastic layered media.Bulletin of Seismological Society of America, 71, 959-971.

Charrier, R., Baeza, O., Elgueta, S., Flynn, J.J., Gans, P., Kay, S.M., Muñoz, N., Wyss, A.R., Zurita, E., 2002. Evidence for Cenozoic extensional basin development and tectonic inversion south of the flat-slab segment, southern Central Andes, Chile (33 $-36^{\circ}$ S.L.). Journal of South American Earth Sciences, 15, 117-139.

Christensen, D.H., Ruff, L.J., 1988.Seismic Coupling and outer rise earthquakes. Journal of 21 Geophysical Research, 93, 13,421-13,444.

22 Comte, D., Farías, M., Charrier, R.,Gonzalez, A., 2008. Active Tectonics in the Central Chilean Andes: 3D Tomography Based on the Aftershock Sequence of the 28 August 2004 Shallow Crustal Earthquake. American Geophysical Union, Fall Meeting 2008, abstract \#T41A-1932.

Farías, M., 2007. Tectonique, erosion et evolution du relief dans les Andes du Chile Central au cours du neogene. Ph.D. Thesis, Universite Toulose III, 238 p., Santiago de Chile.

27 Farías, M., Comte, D., Charrier, R., Martinod, J.,Tassara, A., Fock, A., 2008. Crustal-scale structural architecture of the Central Chile Andes based on 3D seismic tomography, seismicity, and surface geology: Implications for mountain building in subduction zones. Submitted to Earth and Planetary Science Letters, 2008.

Farías, M., Comte, D., Charrier, R., Martinod, J., Tassara, A., 2010. Lithospheric architecture of the Andean margin in Central Chile based on the geometry of seismological structures and surface geology: Implications for mountain building in subduction zones. Tectonics, 29, TC3006, doi: 10.1029/2009TC002480. 
1 Fojtíková, L, Zahradník, J., 2014. A new strategy for weak events in sparse networks: the first2 motion polarity solutions constrained by single-station waveform inversion. Seismological Research 3 Letters, 85, 1265-1274, doi: 10.1785/0220140072

4 Giambiagi, L., Ghiglione, M., Cristallini, E., Bottesi, G., 2009, Características estructurales del 5 sector sur de la faja plegada y corrida de Malargüe $\left(35^{\circ}-36^{\circ} \mathrm{S}\right)$ : distribución del acortamiento e influencia de estructuras previas. Revista de la Asociación Geológica Argentina, 65, 140-153.

7 Harmsen, S.C., Rogers, A.M., 1986. Inferences about the local stress field from focal mechanisms: 8 applications to earthquakes in the southern Great Basin of Nevada. Bulletin of the Seismological 9 Society of America, 76, 1560-1572.

10 Havskov, J., Ottemöller, L., Canabrava, R.L.P., 2007. SEISAN: Multiplatform implementation of MINISEED/SEED. Orfeus Newsletter 7 (2).

12 Janský, J., Zahradník, J., Plicka, V., 2009. Shallow earthquakes: shallower than expected?.Studia 13 Geophysica et Geodaetica, 53, 261-268.

14 Kendrick, E., Bevis, M., Smalley, R.J., Brooks, B.A., Barriga, R., Lauría, E., Souto, L.P., 2003. The Nazca-South America Euler vector and its rate of change. Journal of South American Earth 16 Sciences, 16, 125-131.

17 Krížová, D., Zahradník, J., Kiratzi, A., 2013. Resolvability of isotropic component in regional seismic moment tensor inversion. Bulletin of the Seismological Society of America, 103, 2460 2473, doi: 10.1785/0120120097.

Lange, D., Tilmann, F., Barrientos, S.E., Contreras-Reyes, E., Methe, P., Moreno, M., Heit, B., Agurto, H., Bernard, P., Vilotte, J.P., Beck, S., 2012. Aftershock Seismicity of the 27 February 2010 Mw 8.8 Maule Earthquake Rupture Zone. Earth and Planetary Science Letters, 317-318, 413425.

Lavenu, A., Cembrano, J., 1999. Compressional and transpressional stress pattern for the Pliocene and Quaternary (Andes of central and southern Chile). Journal of Structural Geology, 21, 16691691.

27 Lay, T., 2015. The surge of great earthquakes from 2004 to 2014. Earth and Planetary Science 28 Letters, 409,133-146.

29 Lienert, B., Havskov, J., 1995. A computer program for locating earthquakes locally, regionally and 30 globally. Seismological Research Letters, 66, 26-36.

31 Lupi, M., Miller, S.A., 2014. Short-lived tectonic switch mechanism for long-term pulses of 32 volcanic activity after mega-thrust earthquakes. Solid Earth 5, 13-24. http://dx.doi.org/10.5194/se$33 \quad 5-13-2014$. 
Marot, M., 2013. Flat versus normal subduction zones: A comparison based on 3-D regional travel-

2 time tomography and petrological modeling of Central Chile and Western Argentina $\left(29^{\circ}-35^{\circ} \mathrm{S}\right)$.

3 Ph.D. Thesis, Université de Nice-Sophia Antipolis - UFR Sciences, France, 224pp. (in English).

4 Moreno, M.S., Bolte, J., Klotz, J., Melnick, D., 2009. Impact of megathrust geometry on inversion 5 of coseismic slip from geodetic data: application to the 1960 Chile earthquake. Geophysical Research Letters, L16310 (36). http://dx.doi.org/10.1029/2009GL039276.

Nacif, S., 2012. Seismotectonic of the Nazca plate between $33^{\circ} \mathrm{S}$ and $35^{\circ} \mathrm{S}$ below the interplate 8 seismogenic zone and seismic anisotropy in the crust and the upper mantle of the overriding plate.

9 Ph.D. Thesis,San Juan University, Argentina, 217pp. (in Spanish).

Pardo, M., Comte, D., Monfret, T., 2002. Seismotectonic and stress distribution in the central Chile subduction zone. Journal of South American Earth Sciences, 15, 11-22.

Piquer, J., Castelli, J.C., Charrier, R., Yáñez, G., 2010. El Cenozoico del alto río Teno, Cordillera

Principal, Chile central: estratigrafía, plutonismo y su relación con estructuras profundas. Andean

14 Geology, 37 (1), 32-53.

Reyners, M., Robinson, R., Pancha, A., McGinty, P., 2002. Stresses and strains in a twisted subduction zone - Fiordland, New Zealand. Geophysical Journal International, 148, 637-648.

Rivera, L., Cisternas, A., 1990. Stress tensor and fault plane solutions for population of earthquakes. Bulletin of the Seismological Society of America, 80 (3), 600-614.

Ruiz, S., Grandin, R., Dionicio, V., Satriano, C., Fuenzalida, A., Vignyc, C., Kiraly, E.,Meyer, C., Baez, J.C., Riquelme, S., Madariaga, R., Campos, J., 2013. The Constitución earthquake of 25 March 2012: a large aftershock of the Maule earthquake near the bottom of the seismogenic zone. Earth and Planetary Science Letters, 377-378, 347-357.

Snoke, J.A., 2003. FOCMEC: FOcal MEChanism determinations, International Handbook of Kisslinger, Eds.), Academic Press, San Diego, Chapter 85.12. pp. 1629-1630.

Sokos, E., Zahradník, J., 2008. ISOLA a FORTRAN code and a Matlab GUI to perform multiple-

Sokos, E., Zahradník J., 2013. Evaluating Centroid-Moment-Tensor Uncertainty in the New Version of ISOLA Software.

Spagnotto, S., 2013. Sismicidad entre $34.5^{\circ}-36.5^{\circ} \mathrm{S}$ y $67^{\circ}-71^{\circ} \mathrm{O}$ posterior al sismo de Maule, $\mathrm{Mw}=8.8$, 27/02/2010 y distribuciones de deslizamientos en placa de Nazca para sismos de profundidades mayores a $100 \mathrm{~km}$ en secciones plana y normal entre $31-34^{\circ} \mathrm{S}$. Ph.D. Thesis, Universidad Nacional de San Juan, Facultad de Ciencias Exactas, Físicas y Naturales, Instituto 
1 Spagnotto, S., Triep, E., Giambiagi, L., Lupari, M., 2015. Triggered seismicity in the Andean arc 2 region via static stress variation by the $\mathrm{Mw}=8.8$, February 27 , 2010, Maule earthquake.Journal of 3 South American Earth Sciences,63, 36-47.

4 Tapia, F., 2010. Análisis estructural del sector occidental de la Faja Plegada y Corrida de Malargüe 5 en el curso superior del río Colorado de Lontué $\left(35^{\circ} 18^{\prime}-35^{\circ} 23^{\prime}\right)$, Región del Maule, Chile. Tesis de 6 licenciatura. Universidad de Chile. Inédita. 134 p.

7 Tapia, F., Farías, M., Naipauer, J., 2015. Late Cenozoic contractional evolution of the current arc8 volcanic region along the southern Central Andes ( $35^{\circ} 20$ S).Journal of Geodynamics, 88, 36-51.

9 Zahradník, J., Janský, J., Plicka, V., 2008. Detailed waveform inversion for moment tensors of M 4 10 events; examples from the Corinth Gulf, Greece.Bulletin of the Seismological Society of America, $1198,2756-2771$.

12 Zahradník, J., Custódio, S., 2012. Moment tensor resolvability: Application to southwest Iberia. 13 Bulletin of Seismological Society of America, 102, 1235-1254; doi: 10.1785/0120110216. 